\title{
Constitutional Modernization as a Necessary Condition for the Sustainable Development of the Russian Federation
}

\author{
Veronika Meshcheryagina*, Alexander Savoskin, Mariia Zadorina \\ Ural State University of Economics, Ekaterinburg, Russia \\ ${ }^{*}$ Corresponding author. Email: metsheryagina@yandex.ru
}

\begin{abstract}
The article is devoted to the impact of changes to the Constitution of the Russian Federation on the sustainable development of the country by updating the system of public power. The methodological basis of the research is general scientific (analysis, synthesis, deduction and induction, abstraction, structural and functional method) and specific scientific methods (method of legal construction, technical-legal analysis, formal-logical, formal-legal and system methods). Special attention is paid to the legal constructions "public administration" and "public power". It is established that the state is a single system of functional and territorial elements that interact with each other in order to ensure the sustainable development of the state. The authors conclude that the constitutional modernization has led to a change in the balance of forces in the system of public administration.
\end{abstract}

Keywords: legislation, constitutional reform, public administration, public authority, sustainable development.

\section{INTRODUCTION}

The Constitution has the highest legal force. It is the result of the development of the state and society and a prototype of the legal order in the future [1]. The Constitution specifies the vector of constitutional-legal and socio-economic development of the country.

The Russian Constitution was designed and adopted in very difficult historical conditions such as the period of political instability in 1990-1993. That is why many researchers were convinced that the modernization of the Russian Constitution was inevitable. This point of view was expressed long before the constitutional reform of 2020.

According to article 1 of the Russian Constitution the Russian Federation is a State governed by the rule of law. This legal principle means: the rule of law; real differentiation of the executive, legislative and judicial authorities; observance and protection of the rights, freedoms and legitimate interests of a person and a citizen; the responsibility of the state to citizens and the citizen to the state; effective control and supervision of the implementation of laws and subordinate legislation (prosecutor's supervision, judicial and public control).
These postulates should be specified in the legislation. The perception of the text of the Russian Constitution depends on their compliance.

There is no doubt that the amendments to the Russian Constitution determine the main direction of the development of the public administration system in order to protect the rights and freedoms of man and citizen and ensure the sustainable development of the country.

It seems possible to distinguish the following main directions of the constitutional modernization: establishing the priority of the Russian Constitution over international treaties; strengthening and developing social guarantees; strengthening the role of the Constitutional Court of the Russian Federation; transformation of the order of formation and powers of some public authorities.

The purpose of the article is to substantiate the relationship between the amendments to the Constitution of Russia in 2020 and ensuring the country's sustainable development in the future by updating the public administration system. To do this, it is necessary to analyse the legal structures "public administration and public power", determine their system elements, predict 
the effect of the adopted amendments to the Constitution of the Russian Federation in 2020.

\section{MATERIALS AND METHODS}

The methodological basis of the research is general scientific (analysis, synthesis, deduction and induction, abstraction, structural and functional method) and specific scientific methods (method of legal construction, technical-legal analysis, formal-logical, formal-legal and system methods).

Material for research: the Constitution and other regulatory legal acts of the Russian Federation, scientific articles by Russian and foreign authors, analytical data of the authorities.

The chosen methodology will allow: (1) to compare the legal models of public administration on the basis of the Russian Constitution before and after amendments to it; (2) to identify trends in the sustainable development of the state.

\section{RESULTS AND DISCUSSION}

First of all, the public administration system is based on the basic principles of social management. Social management has a strong-willed character, is focused on achieving socially significant goals in the public or private sphere. Social management has several hierarchical levels regulated by normative legal acts of various legal force.

Public administration is one of the varieties of social management. It is implemented by state and local government bodies. The process of social management (applied to public administration) consists of the legislative and law-making process, managerial decisions making process and their implementation. These multidirectional processes are interrelated, they are observed in administrative-legal, civil-legal and constitutional legal relations.

The people, as the only source of power (Article 3 of the Constitution of the Russian Federation), transferred this power to the state to develop social development goals based on the integration of the interests of various groups. These groups make up the structure of society. That's why constitutional legal rules are the basic prerequisite for the formation of a sustainable development of the country as a whole and the public administration system in particular. This is possible due to the emergence of the following institutions in Russia: state and municipal services; public-private partnership; assessment of the regulatory impact of draft regulations, legal and anti-corruption expertise, etc. These institutions contain some signs of strong-willed management and strengthen the tendency to improve feedback from citizens and their associations. The importance of constitutional and legal regulation is also increasing due to the complexity of the social system, the emergence of new subjects, forms of social activity, especially on the Internet: the development and implementation of the portal "Public Services", "Russian Public Initiative", "Your control", etc.

It should be noted that "public administration" as a legal construction is still not widespread as a generally recognized term in juridical science. This term is still not properly reflected both at the level of the legislation of the Russian Federation and at the level of by-laws. Therefore, this term requires significant analysis.

For example, B. Milner notes that public administration is a purposeful activity of the system of state executive authorities that performs the functions of public administration on the basis of laws. He divides this activity into organizing, subordinate, executiveadministrative and regulatory [2].

Some authors consider the term "public administration" as a process of implementing the functions of the state, not as a function. For example, K.V. Cherkasov believes that public administration is carried out only with the aim of organizing the proper work of the apparatus of a state body, allowing this body to implement its functions in order to achieve the tasks assigned to it [3].

At the same time, scientists most often consider municipal administration (local government) as a "complementary" function of public administration, the purpose of which is to improve the quality of life of the population on the territory of the municipality [4-5].

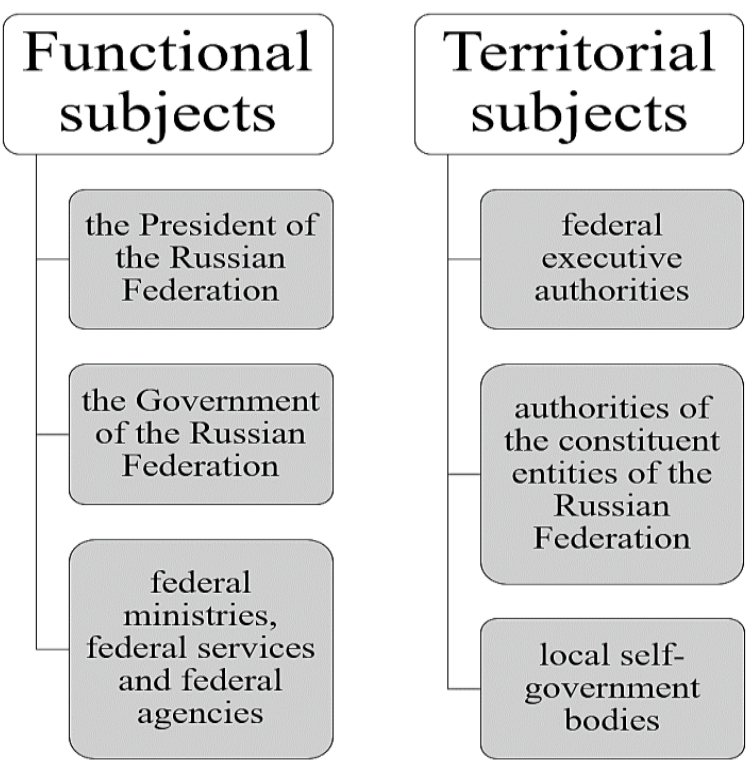

Figure 1 Functional and territorial elements of the state.

The amendments to the text of the Russian Constitution in 2020 created the prerequisites for a significant transformation of the public administration 
system. The appearance of the category "public power" in the text of the Constitution forces us to pay attention to the emergence of a new constitutional legal category "public administration" as one of the forms of activity of public authorities. These bodies influence public relations, they use their powers for the sustainable development of society and territories within the borders of the Russian Federation.

The amendments to the Russian Constitution have significantly changed the balance between centralization and decentralization of public administration. Constitutional legal rules on the competence of public authorities play an important role in finding this balance. These legal rules are developed in laws and other normative legal acts. The correct classification of the powers that make up the content of managerial influence is also of particular importance [6].

Without a doubt the effectiveness of public administration depends on the balance search in the structure and powers of public authorities at the level of federal and regional legislation. There are two categories of subjects of managerial activity in the concept of public administration to find this balance: "functional" and "territorial" (Figure 1).

This constitutional and legal model of public administration has been functioning since the adoption of the Constitution of the Russian Federation in 1993. However, the content of the balance between the elements and subjects of public administration was significantly transformed in 2020, due to the amendments to the Russian Constitution.

Let us consider some directions of the constitutional transformation of this balance.

First of all, the constitutional changes have led to a significant transformation of the system of checks and balances between the branches of government. At the same time, the role and positions of the President of the Russian Federation were strengthened [7-9].

The procedure of "consent" of the State Duma of the Federal Assembly of the Russian Federation has been transformed into "approval of the candidacy" of the Prime Minister due to the amendments to Article 111 of the Russian Constitution. At the same time the President of the Russian Federation has the right to dissolve (previously, he had to dissolve it imperatively) the State Duma of the Federal Assembly after three times rejecting the submitted candidates for the post of Prime Minister of the Russian Federation. The change of this legal rule (moving away from imperativeness to dispositivity) still preserves the rather vulnerable position of the State Duma of the Federal Assembly of the Russian Federation in the system of separation of powers [10].

The amendments to Article 110 of the Constitution of the Russian Federation have consolidated the approach according to which the President of the Russian Federation is more related to the executive authorities: the executive power of the Russian Federation is carried out by the Government of the Russian Federation under the general leadership of the President of the Russian Federation. At the same time, the Government of the Russian Federation directs the activities of federal executive bodies except of federal executive bodies whose activities are managed by the President of the Russian Federation (Figure 2).

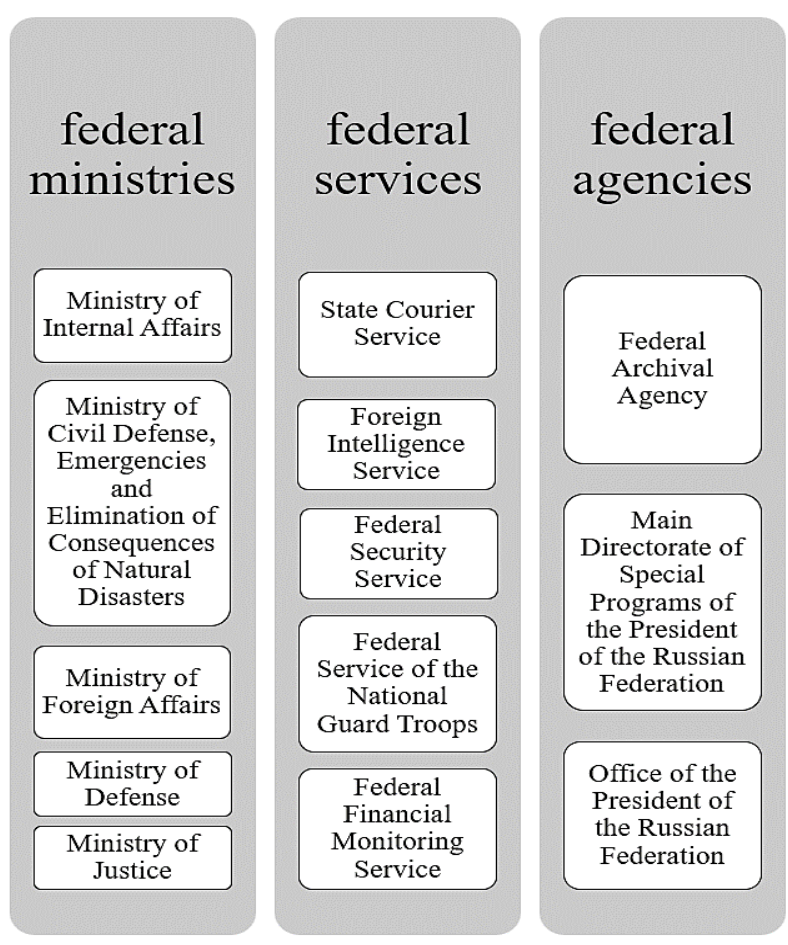

Figure 2 Federal executive bodies whose activities are managed by the President of the Russian Federation.

The constitutional amendments to Article 107 of the Russian Constitution on the possibility of the Head of State to appeal to the Constitutional Court of the Russian Federation within the framework of the legislative process (when the chambers of Parliament overcame the presidential veto) significantly strengthened the role of the President of the Russian Federation in balance of branches of power. If the Constitutional Court of the Russian Federation confirms the constitutionality of a federal law, the President of the Russian Federation signs it within three days from the moment of making the decision. If the Constitutional Court of the Russian Federation does not confirm the constitutionality of the federal law, the President of the Russian Federation returns the unsigned federal law to the State Duma of the Federal Assembly.

The appearance of a new state body at the constitutional level (the State Council of the Russian Federation) makes adjustments to the distribution of the 
balance of power. Federal Law No. 394-FZ of December 8, 2020 "On the State Council of the Russian Federation" defined this body as a constitutional state body formed by the President of the Russian Federation in order to ensure the coordinated functioning and interaction of bodies that are part of a single system of public power, to determine the main directions of domestic and foreign policy of the Russian Federation and priority directions of socioeconomic development of the state. Thus, the activity of the State Council is connected with another new constitutional term "unified system of public power". This system includes all authorities without exception. Their activities are aimed at creating conditions for the sustainable development of the state.

Moreover, the Law of the Russian Federation on the amendment to the Constitution of the Russian Federation No. 1-FKZ of March 14, 2020 is aimed at improving the organization of public power.

The category of "public power" is not new both in the science of constitutional law and in law enforcement practice. This category was introduced into Russian Law by the Resolution of the Constitutional Court of the Russian Federation No. 1-P of January 24, 1997, where this concept includes state power and local selfgovernment. The Constitutional Court of the Russian Federation has determined that local self-government and its bodies are a type of public authority. The thesis that public power can be state or municipal was also repeated by the Constitutional Court of the Russian Federation in the resolution No. 3-P of January 15, 1998.

The position of the Constitutional Court of the Russian Federation is supported by well-known constitutional scientists. For example, N.S. Bondar notes that public power as a political function to ensure the normal functioning of society is objectified through law in the construction of state and municipal power [1]. In the same way V.E. Chirkin notes that local selfgovernment exists and operates in the system of general relations and relations for the management of society within the framework of this state [11]. Local selfgovernment is an element of the system. It must comply with system-wide requirements in accordance with the principles of systems theory.

In accordance with the amendments to Chapter 8 of the Constitution of the Russian Federation, a new principle of building a vertical system of power is established: local self-government bodies and state authorities form a single system of public power in the Russian Federation and interact for the most effective solution of tasks in the interests of the population living in the relevant territory (part 3 of Article 132 of the Constitution of the Russian Federation). At the same time, the provisions of Article 12 of the Constitution of the Russian Federation remain in force (local selfgovernment bodies are not included in the system of state authorities).
Professor S.A. Avakian emphasizes that the independence of local self-government is relative, since the state establishes the legal framework, legally defines the limits of the powers of local self-government, its place in the relations of the state, society and the individual. It is also impossible to talk about the absolute isolation of local self-government bodies from state authorities. Local self-government bodies consider issues of local significance in accordance with laws and other regulatory legal acts adopted by federal and regional state authorities. Moreover, local self-government bodies may be delegated with several state powers according to paragraph 2 of Article 132 of the Constitution of the Russian Federation. In this case, the transfer of the necessary material and financial resources is a prerequisite. The implementation of the transferred powers is controlled by state bodies [12].

The Constitutional Court of the Russian Federation indicated that the unity of the system of public power is primarily understood as functional unity, which does not exclude organizational interaction of state authorities and local self-government bodies when solving tasks in the relevant territory. This does not negate the independence of local self-government within its powers and does not indicate the entry of local self-government bodies into the system of state authorities (Conclusion of the Constitutional Court of the Russian Federation No. 1-Z of March 16, 2020). Thus, local self-government bodies are still not included in the system of state power.

The constitutional modernization of local selfgovernment bodies also includes a number of other changes. The new version of Article 131 of the Russian Constitution defines that the structure of local selfgovernment bodies is determined by the population independently, but "in accordance with the general principles of the organization of local self-government in the Russian Federation established by federal law". In addition, the text of the same article was supplemented with a new paragraph stating that state authorities can participate in the formation of local self-government bodies in the order and cases established by federal law.

Another important novelty is the consolidation of the fundamental goal of interaction between the authorities within the framework of a single system of public power. This goal is the interests of the population. Moreover, "the interests of the population" as a legal category is included in the legal discourse. This legal category is gaining the highest degree of consolidation due to the indication in the text of Chapter 8 of the Constitution of Russia. This has never happened before. It implies that the introduction of the category "interests of the population" into the constitutional text is of particular importance in determining the priority areas for sustainable development of a particular municipality and the entire state. 
Thus, the category "unity of public power" was introduced into the constitutional and legal space due to the amendments to the Constitution of the Russian Federation in 2020. The unity of public power means that state authorities and local self-government bodies jointly perform their fundamental function - ensuring the supremacy of human rights and freedoms throughout the territory of the Russian Federation and creating conditions for the socio-economic development of the state.

\section{CONCLUSION}

The constitutional modernization of public administration is aimed at forming the unity of public power in the Russian Federation both vertically and horizontally. This approach is combined with the theory of social systems. It implies that the state is a single system of functional (the President of the Russian Federation, the Government of the Russian Federation, ministries, departments, civil servants, etc.) and territorial elements (constituent entities, municipalities).

The advantages of this approach are to ensure a unified policy aimed at the full implementation of the "interests of the population", creating conditions for the sustainable development of the state. At the same time, the control and responsibility of public authorities for the quality of implementation of the domestic and foreign policy, priority areas of socio-economic development of the country, as well as for creating optimal living conditions for a person and a citizen in any part of the Russian Federation is being strengthened.

The disadvantage of the updated system of public administration is the strengthening of the role of the President of the Russian Federation. However, the strengthening and concentration of power in one hand can lead to tragic consequences for the unity of the state and for the preservation of harmony in society (when the institutions of democracy are poorly developed, civil society is in the process of formation).

Thus, the constitutional modernization of public administration is a necessary condition for ensuring the sustainable development of the country. Nevertheless, it is necessary to ensure that the balance of forces in the system of separation of powers is maintained during its implementation.

\section{AUTHORS' CONTRIBUTIONS}

All authors contributed to the design and implementation of the research. V. Meshcheryagina focused on theoretical sources, A. Savoskin analysed legislation, M. Zadorina analysed law enforcement practice. All authors discussed the results and contributed to the final manuscript.

\section{REFERENCES}

[1] N.S. Bondar, Local self-government and constitutional justice. Constitutionalization of municipal democracy in Russia. Norm, 2008.

[2] B.Z. Milner, T.M. Orlova, Organization of innovation creation: horizontal connections and management. Infra-M, 2013.

[3] K.V. Cherkasov, On the question of the content of the concept of "public administration" in the Russian legal science. Administrative and municipal law, 11 (2008) pp. 10-14.

[4] A.Yu. Klevyn, A.I. Kogi, State and municipal management and its importance for modern society. Scientific Herald YUIM, 3 (2016) pp. 85-91.

[5] V.N. Leksin, V.I. Leksin, N.N. Chuchalina, The quality of public and municipal administration and administrative reform. Europroject, 2006.

[6] N.S. Bondar, A.A. Dzhagaryan State power and (or) local self-government: in search of an optimal model of relationships. Constitutional and municipal law, 24 (2007) pp. 23-26.

[7] W.E. Pomeranz, R. Smyth, Russia's 2020 constitutional reform: The politics of institutionalizing the status-quo. Russian Politics 6 (1) (2021) pp. 1-5. DOI: https://doi.org/10.30965/24518921-00601001.

[8] I.A. Vetrenko, The beginning of a large-scale political reform in Russia: a new turn in 2020. Law Enforcement Review, 4(1) (2020) pp. 14-20. DOI: https://doi.org/10.24147/2542-1514.2020.4(1).1420.

[9] N.A. Bobrova, Twenty years and twenty drawbacks of the Russian Constitution. Law Enforcement Review 4(1) (2020) pp. 21-28. DOI: https://doi.org/10.24147/2542-1514.2020.4(1).21 28.

[10] A. Shashkova, M. Verlaine, E. Kudryashova, On Modifications to the Constitution of the Russian Federation in 2020. Russian Law Journal 8 (1) (2020) pp. 60- 83. DOI: https://doi.org/10.17589/2 309-8678-2020-8-1-60-83.

[11] V.E. Chirkin, State and municipal management. Yurist, 2004.

[12] S.A. Avakyan, Local self-government as a form of public power: constitutional expectations and real constructions. Legal world, 1(2020) pp. 15-20. 